British Journal of Education

Vol.8, Issue 6, pp.1-17, June 2020

Published by ECRTD- UK

Print ISSN: ISSN 2054-6351: Online ISSN: ISSN 2054-636X

\title{
INFLUENCE OF GENDER AND LOCATION ON STUDENTS CONCEPTIONS OF HEAT ENERGY IN SENIOR SECONDARY SCHOOL PHYSICS
}

\author{
${ }^{1}$ Nduji, C. C. and ${ }^{2}$ Madu, B.C Ph.D \\ $1 \& 2$ Department of Science Education University of Nigeria, Nsukka
}

\begin{abstract}
The study determined the influence of gender and location on students' conceptions of heat energy in senior secondary school physics. Two research questions and two null hypotheses guided the study. The study adopted ex-post facto research design. 6,270 senior secondary school two (SSS2) physics students in all the government owned educational secondary schools in Onitsha Education Zone of Anambra State, Nigeria; during 2018/2019 academic session comprised the population. The sample size of 357 senior secondary two (SS2) students drawn from the population was used for the study. Multi-stage sampling procedure was used in composing the sample. Heat Energy Conception Test (HECT) with 16 theory items was adapted by the researchers to measure students' conception of heat energy. The instrument was validated by three experts from the Department of Science Education, University of Nigeria, Nsukka. The internal consistency index of the instrument was calculated to be 0.747 using Cronbach Alpha formula ( $\alpha)$. Frequency and percentage was used to answer all the research questions. Chi-square was used in testing the two null hypotheses of the study. The study revealed that gender and location has no significant influence on students' conceptions of heat energy in senior secondary school physics. In light of the findings, recommendations were made by the researchers.
\end{abstract}

KEYWORDS: students' conceptions, gender, location, heat, energy

\section{INTRODUCTION}

In recent time, in-depth knowledge of physics concept is needful as it forms the base for solving many problems within the environment since the world is technologically advancing. This is one of the reasons for understanding of physics concepts by students and society at large. The idea or understanding a student possesses about a concept is termed students conceptions. Students conceptions was highlighted as a major challenge in physics at the international seminar on conception in science and mathematics held precisely in 1983 and 1987 in Cornell University, Ithaca, USA (Zudonu, 2013). However, the main focus of students' conceptions of physics concepts is on the way in which students obtain new knowledge and skills and the way in which existing knowledge and skills can be modified (Shuell, 2006). This is in agreement with Orji (2013) who opined that student may either have scientific (sound) conception (SC) or partial understanding (PU) or alternative conception (AC) or naive conception (NC) about a concept. Scientific conception indicates correct or competent information about a topic. Partial understanding shows learners' incomplete or biased knowledge about a concept. Alternative 
British Journal of Education

Vol.8, Issue 6, pp.1-17, June 2020

Published by ECRTD- UK

Print ISSN: ISSN 2054-6351: Online ISSN: ISSN 2054-636X

conception represents learners' ideas which are inconsistent with right conception. Naive conception deduces the failure of a student to formulate an answer. Students at this level admit that they have some exposure about the concept but could not assess or remember it (Amaechi, 2013). However, previous studies by different researchers on students conceptions in physics have revealed that that physics students hold incomplete or inaccurate conception in some physics concepts like; electric circuit (Madu, 2004), electricity and magnetism (Bekele, Jeanne \& Temesgen, 2013; Demirci \& Cirkinoglu, 2004); force and motion (Ugwuanyi, 2012); electric resistance (Tao, Sanjun, Jingying \& Yongjun, 2018); elasticity (Agumuoh, 2010); real and virtual experimentation on electric circuit as investigated by Zacharia (2017). Thus, there comes the need to investigate on students' conceptions, specifically on heat energy since other studies are on different physics concept.

Heat energy is usually misconceived by students due to their experiences within the environment. For instance, students often talk about 'using heat energy' or 'losing heat energy'. The students imagine that something has lots of energy, and then as the object functions, it uses up heat energy until it runs out. Also, students' sees heat energy as been produced by object (such as blanket). To this effect, the students move further defining heat energy as the temperature of an object (FriesGaither, 2009). The above example indicates wrong conceptions of students about heat energy. Thus, students with such conceptions fails to understand that heat energy is the result of the movement of tiny particle called atoms, molecules or ions in solids, liquid and gases (https://www.sciencelearninghub.org.nz). Based on these wrong conceptions students possess, they achieve poorly on heat energy questions as outlined by West Africa Examinations Council (WAEC) (Chief Examiners Report, 2016-2017). Based on this, the study tended to investigate if; gender has influence on heat energy conception of secondary school physics students.

Being male or female (i.e. gender) is a physical or social attribute given to an individual by the society. According to Maicons and Gerber cited in Zudonu (2013), gender is socially constructed definition of women and men. This means that the determinant of gender can be attributed to conception of facts, functions and roles given to men and women in the society. For instance, throughout life (birth to death) human feelings, thought and actions reflect the social definition that people attach to gender which affect the individuals' daily activities positively or negatively (Nwosu, 2011). This means that the normative way (or standard) people act and feel in the manner the society subscribes to, is an effect of gender. Though, there has been no consistent report of various studies on the influence of gender on students' conceptual understanding of physics concept in senior secondary schools. These studies include Arigbadu and Miji (2014) and Bilesanmi-Awoderu (2006) whose reports showed that there are no longer distinguishing differences in the cognitive, effective and psychomotor skills of students in respect to gender. On the contrary, Ugwuanyi (2012) reported that gender has significant influence on students' conceptual understanding of force and motion in the direction of the female students. Also, Chinyere and Madu (2014) who reported that there is significant effect in the mean conceptual change scores of boys and girls when taught the concept of refraction of light. In the same light, Fatoba and Aladejana (2014), observed the existence of disparity between male and female students' in Nigeria physics. Therefore, in other to checkmate this inconsistence to some extent, the researchers were geared towards investigating the influence of gender (i.e male and female) on 
students' conceptions of heat energy. Male and female students may be influenced by the situated point of learning environment (i.e school location).

School location refers to the particular place, in relation to other areas in the physical environment (rural or urban), where the school is sited (Ntibi \& Edoho, 2017). This implies that school can be sited either in urban or rural areas. However, school location has significant difference on students' conceptual understanding of force and motion (Nworgu, Ugwuanyi \& Nworgu, 2013). Furthermore, (Hofstein \& Kesner, 2016; Musibau \& Johnson, 2017) findings showed that school location has no significant difference on students' conceptions in chemistry. These different finding indicates that the influence of school location as pointed out in the above discussion has not been ascertained.

In light of the above discussion, it can be seen that the influence of both gender and school location on students' conceptions of heat energy is still inconclusive. Thus, the present study sought to determine the influence of gender and location on students' conceptions of heat energy in senior secondary school physics. Hence, the purpose of the study was to determine influence of gender and location on students' conceptions of heat energy in senior secondary school physics. Specifically, the study intends to determine the:

1. Influence of gender on students' conception of heat energy in senior secondary school physics.

2. Influence of location on students' conception of heat energy in senior secondary school physics.

\section{Research Questions}

The following research questions guided the study;

1. What is the influence of gender on students' conception of heat energy in senior secondary school physics?

2. What is the influence of location on students' conception of heat energy in senior secondary school physics?

\section{Hypotheses}

The following null hypothesis guided the study. All the hypotheses were tested at 0.05 level of significance.

H01. Students' conception of heat energy in senior secondary school physics is not significantly influenced by gender.

H02. Students' conception of heat energy in senior secondary school physics is not significantly influenced by school location. 


\section{METHODS}

The study adopted Ex-post facto research design. According to Nworgu (2015), Ex-post facto design is a research design which is used to study the influence of variables that cannot be manipulated (i.e. non-manipulable independent variables) such as gender, school location etc. The population of the study comprised of 6,270 senior secondary school two (SSS2) physics students (that is 2,752 male and 3,386 female) in all the government owned educational secondary schools in Onitsha Education Zone during 2018/2019 academic session. The choice of SS2 students was because the units to be used for the study were contained in SS2 scheme of work, and also the students might have learnt the fundamentals of heat energy in their penultimate year (SS1). The sample size of the study was 357 senior secondary two (SS2) students drawn from the population. 262 SS2 students are from urban and 95 are from rural schools. Multi-stage sampling procedure was used in composing the sample. At the initial stage, purposive sampling technique was used to select twenty (20) co-educational schools from the thirty-two (32) schools in the three local government areas (LGA) that was used for the study. In the second stage, simple random sampling technique of balloting with replacement was used to draw three (3) schools from each LGA. Thirdly, proportionate stratified random sampling was used to draw number of students to be studied in each school that was sampled from each LGA resulting to the total number of 357 students.

The instrument used for the study was Heat Energy Conception Test (HECT) with16 items to measure students' conception of heat energy. This instrument was originally developed by Yeo and Zadnik (2001) and adapted by the researchers. However, the researchers made some modifications on the items by adding more items measuring heat and discarding those items measuring temperature. This was aimed at ensuring consistency in measuring students' conception of heat energy. Each item was arranged and scored in four point scale (i.e. 3, 2, 1 and 0). However 3 were assigned to scientific conception; 2 were assigned to partial understanding; while 1 and 0 were assigned to alternative conception and no conception respectively.

The instrument was validated by three experts from the Department of Science Education, University of Nigeria, Nsukka. Cronbach Alpha formula $(\alpha)$ was used to estimate the internal consistency reliability of the HECT. With this formula, the internal consistency index of the instrument was calculated to be 0.747 . Frequency and percentage was used to answer research questions $1,2 \& 3$. Chi-square was used in testing the two null hypotheses of the study. 
British Journal of Education

Vol.8, Issue 6, pp.1-17, June 2020

Published by ECRTD- UK

Print ISSN: ISSN 2054-6351: Online ISSN: ISSN 2054-636X

\section{Results}

Research question 1: What is the influence of gender on students' conception of heat energy in senior secondary school physics?

Table 1: Frequency and Percentage Analysis of Influence of Gender on Students' Conception of Heat Energy in Senior Secondary School Physics

\begin{tabular}{|c|c|c|c|c|c|c|c|c|}
\hline & & Male $(n=21$ & & & Female (n & 40) & & \\
\hline Item No. & $\begin{array}{c}\text { SC } \\
\mathbf{f}(\%) \\
\end{array}$ & $\begin{array}{c}\mathbf{P U} \\
\mathbf{f}(\%) \\
\end{array}$ & $\begin{array}{c}\mathrm{AC} \\
\mathrm{f}(\%) \\
\end{array}$ & $\begin{array}{c}\mathrm{NC} \\
\mathrm{f}(\%) \\
\end{array}$ & $\begin{array}{c}\mathbf{S C} \\
\mathbf{f}(\%) \\
\end{array}$ & $\begin{array}{c}\mathbf{P U} \\
\mathbf{f}(\%)\end{array}$ & $\begin{array}{c}\mathrm{AC} \\
\mathrm{f}(\%) \\
\end{array}$ & $\begin{array}{c}\mathrm{NC} \\
\mathrm{f}(\%) \\
\end{array}$ \\
\hline 1 & $93(26.1)$ & $39(10.9)$ & $44(12.4)$ & $41(11.5)$ & $70(19.6)$ & $24(6.7)$ & $23(6.4)$ & $23(6.4)$ \\
\hline 2 & $4(1.1)$ & $15(4.2)$ & $36(10.1)$ & $162(45.4)$ & $3(0.8)$ & $10(2.8)$ & $27(7.6)$ & $100(28.0)$ \\
\hline 3 & $4(1.1)$ & $10(2.8)$ & $13(3.6)$ & $190(53.2)$ & $6(1.7)$ & $2(0.5)$ & $9(2.5)$ & $123(34.5)$ \\
\hline 4 & $44(12.3)$ & $11(3.1)$ & $26(7.3)$ & $136(38.1)$ & $24(6.7)$ & $8(2.2)$ & $29(8.1)$ & $79(22.1)$ \\
\hline 5 & $1(0.3)$ & $11(3.1)$ & $31(8.6)$ & $174(48.7)$ & $1(0.3)$ & $10(2.8)$ & $26(7.3)$ & $103(28.9)$ \\
\hline 6 & $1(0.3)$ & $5(1.4)$ & $46(12.9)$ & $165(46.2)$ & $3(0.8)$ & $7(2.0)$ & $43(12.0)$ & $87(24.3)$ \\
\hline 7 & $3(0.8)$ & $13(3.6)$ & $39(10.9)$ & $162(45.4)$ & $0(0)$ & $2(0.5)$ & $17(4.7)$ & $121(33.9)$ \\
\hline 8 & $4(1.1)$ & $26(7.3)$ & $41(11.5)$ & $146(40.9)$ & $2(0.5)$ & $20(5.6)$ & $28(7.8)$ & $90(25.2)$ \\
\hline 9 & $8(2.2)$ & $13(3.6)$ & $17(4.8)$ & $179(50.1)$ & $6(1.7)$ & $1(0.3)$ & $9(2.5)$ & $124(34.7)$ \\
\hline 10 & $1(0.3)$ & $6(1.7)$ & $25(7.0)$ & $185(51.8)$ & $0(0)$ & $3(0.8)$ & $17(4.8)$ & $120(33.6)$ \\
\hline 11 & $1(0.3)$ & $11(3.1)$ & $30(8.4)$ & $175(49.0)$ & $0(0)$ & $10(2.8)$ & $19(5.3)$ & $111(31.1)$ \\
\hline 12 & $1(0.3)$ & $6(7.3)$ & $27(7.6)$ & $184(51.5)$ & $2(0.5)$ & $6(1.7)$ & 21(5.9) & $111(31.1)$ \\
\hline 13 & $4(1.1)$ & $26(7.3)$ & $27(7.6)$ & $160(44.8)$ & $1(0.3)$ & 13(3.6) & $29(8.1)$ & $97(27.2)$ \\
\hline 14 & $0(0)$ & $5(1.4)$ & $29(8.1)$ & $183(51.2)$ & $0(0)$ & $1(0.3)$ & $14(3.9)$ & $125(35.0)$ \\
\hline 15 & $20(5.6)$ & $21(5.9)$ & $16(4.5)$ & $160(44.8)$ & $13(3.6)$ & $17(4.8)$ & $8(2.2)$ & $102(28.6)$ \\
\hline 16 & $1(0.3)$ & $14(3.9)$ & $13(3.6)$ & $189(52.9)$ & $0(0)$ & $14(3.9)$ & $8(2.2)$ & $118(33.2)$ \\
\hline $\begin{array}{l}\text { Overall } \\
\text { No. of } \\
\text { Students }\end{array}$ & $12(3.4)$ & $14(4.2)$ & $29(8.1)$ & $162(45.4)$ & $8(2.2)$ & $9(2.5)$ & $20(5.6)$ & $102(28.6)$ \\
\hline
\end{tabular}

NB: The overall number of students in each level of conception is equal to frequency divided by number of items (ie. 16); $\mathrm{n}=$ Number of Respondent; $\mathrm{NC}=$ No Conception; $\mathrm{AC}=$ Alternative Conception; $\mathrm{PU}=$ Partial Understanding; $\mathrm{SC}=$ Sound/Scientific Conception; $\mathrm{f}=$ Frequency; \%= Percentage 
British Journal of Education

Vol.8, Issue 6, pp.1-17, June 2020

Published by ECRTD- UK

Print ISSN: ISSN 2054-6351: Online ISSN: ISSN 2054-636X

Table 1, shows that in item1 of Heat Energy Conception Test (HECT), 93 students have SC and 39 students have PU while 44 students have AC and 41 students have NC for male student respondents of item1. For female students; 70 students have SC and 24 students have PU while 23 students have $\mathrm{AC}$ and 23 students have $\mathrm{NC}$ of item1. Also in item2, 4 students have SC and 15 students have PU while 36 students have AC and 162 students have NC for male student respondents of item2. For female students; 3 students have SC and 10 students have PU while 27 students have AC and 100 students have NC of item2. In item3, 4 students have SC conception and 10 students have PU while 13 students have AC and 190 students have NC for male student respondents of item3. For female students; 6 students have SC and 2 students have PU while 9 students have AC and 123 students have NC of item3.

In item4, 44 students have SC and 11 students have PU while 26 students have AC and 136 students have NC all for male student respondents of item4. However, female students who have SC are 24 and 8 students have PU while 29 students have AC and 79 students have NC of item4. In item5, 1 student has SC and 11 students have PU while 31 students have AC and 174 students have NC all for male student respondents of item5. However, female students who have SC are 1 and 10 students have PU while 26 students have AC and 103 students have NC of item5. In item6, 1 student has SC and 5 students have PU while 46 students have AC and 165 students have NC all for male student respondents of item6. However, female students who have SC are 3 and 7 students have PU while 43 students have AC and 87 students have NC of item6. In item7, 3 students have SC and 13 students have PU while 39 students have AC and 162 students have NC all for male student respondents of item7. However, female students who have SC are 0 and 2 students have PU while 17 students have AC and 120 students have $\mathrm{NC}$ of item7. In item8, 4 students have SC and 26 students have PU while 41 students have AC and 146 students have NC all for male student respondents of item8. However, female students who have SC are 2 and 20 students have PU while 28 students have AC and 90 students have $\mathrm{NC}$ of item8.

In item9, female students who have SC are 6 and 1 students have PU while 9 student have AC and 124 students have NC of item9. However, male students who have SC, PU, AC and NC of item9 are 8, 13, 17 and 179 respectively. In item10, female students who have SC are 0 and 3 students have PU while 17 student have $\mathrm{AC}$ and 120 students have $\mathrm{NC}$ of item10. However, male students who have SC, PU, AC and NC of item 10 are 1, 6, 25 and 185 respectively. In item11, female students who have SC are 0 and 10 students have PU while 19 student have AC and 111 students have NC of item11. However, male students who have SC, PU, AC and NC of item11 are 1, 11, 30 and 175 respectively.

In item12, female students who have SC are 2 and 6 students have PU while 21 student have AC and 111 students have NC of item12. However, male students who have SC, PU, AC and NC of item 12 are 1, 6, 27 and 184 respectively. In item13, female students who have SC are 1 and 13 students have PU while 29 student have AC and 97 students have NC of item13. However, male students who have SC, PU, AC and NC of item13 are 4, 26, 27 and 160 respectively. In item14, female students who have SC are 0 and 1 students have PU while 14 student have AC and 125 students have NC of item14. However, male students who have SC, PU, AC and NC of item14 are $0,5,29$ and 183 respectively. 
In item15, female students who have SC are 13 and 17 students have PU while 8 student have AC and 102 students have NC of item15. However, male students who have SC, PU, AC and NC of item 15 are 20,21, 16 and 160 respectively. In item16, female students who have SC are 0 and 14 students have PU while 8 student have AC and 118 students have NC of item16. However, male students who have SC, PU, AC and NC of item16 are 1, 14, 13 and 189 respectively.

The above discussion also shows that PU, AC and NC is a high extent male and female students. Thus, few students have SC of heat energy in senior secondary school physics. However, Table1 analysis also showcased the overall $\mathrm{f}(\%)$ of male students that have SC-12(3.4\%); PU-14(4.2\%); AC-29(8.1\%) and NC-162(45.4\%). For female students; $8(2.2 \%)$ have SC; $9(2.5 \%)$ have PU; $21(5.6 \%)$ have AC and 102(28.6\%) have NC. This indicates that both male and female students have highest frequency on $\mathrm{NC}$ which is naive understanding of heat energy concept. NC is followed by $\mathrm{AC}$, PU and SC which has the lowest frequency. Thus, male and female students' conception of heat energy is not scientific or sound. However, the chart below (fig.3) revealed how students response with categorizes are been distributed among school location. The chart has its tallest and smallest bar in both locations (urban and rural) which is NC and SC respectively. This shows that male and female students do not have the required conception of HECT since SC has the smallest bar. Nevertheless, the influence of school location on students' conception of heat energy was further investigated by testing the hypothesis below.

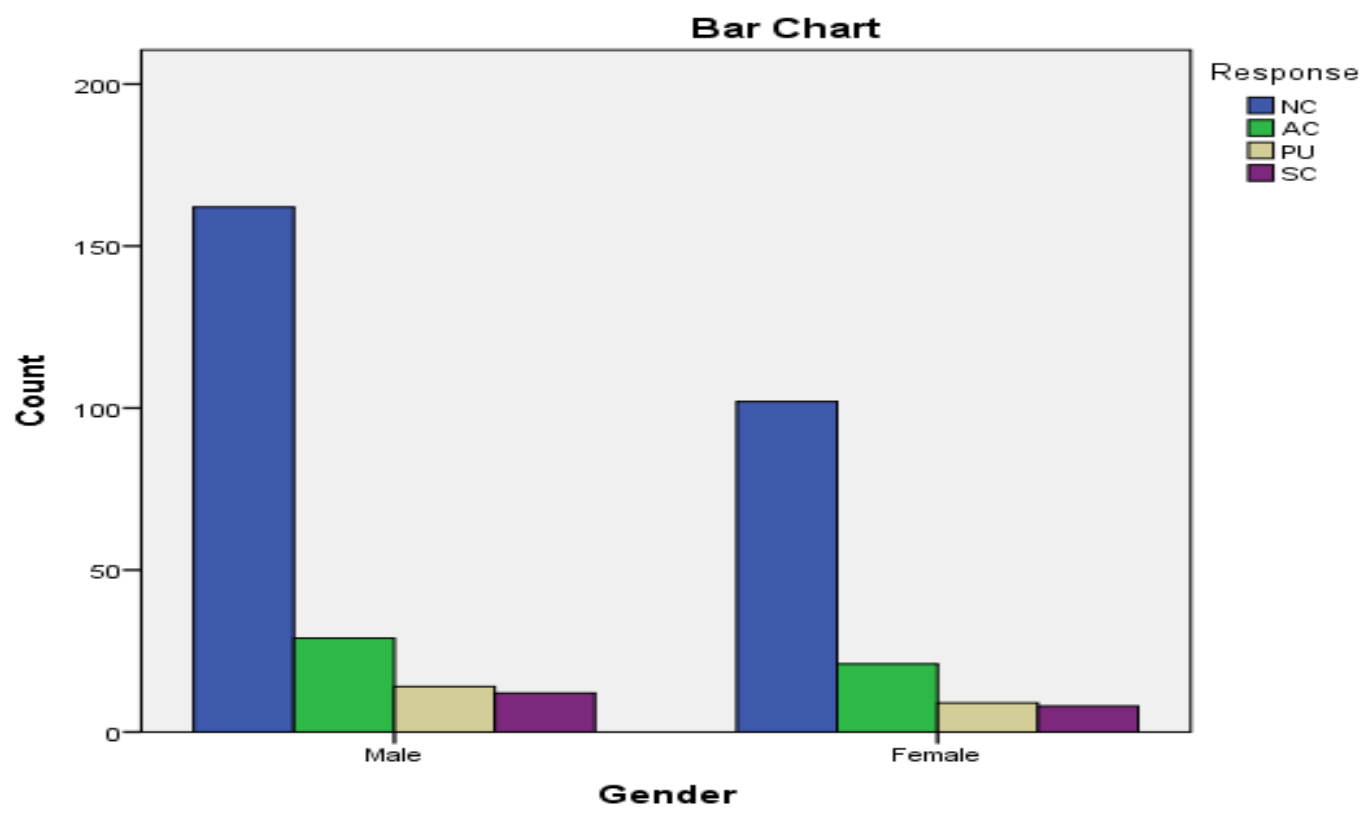

Fig. 1: Histogram Showing the Distribution of Male and Female Overall Conception on Heat Energy Conception Test (HECT) 
British Journal of Education

Vol.8, Issue 6, pp.1-17, June 2020

Published by ECRTD- UK

Print ISSN: ISSN 2054-6351: Online ISSN: ISSN 2054-636X

Hypotheses 1: Students' conception of heat energy in senior secondary school physics is not significantly influenced by gender.

Table 2: Chi-square Analysis of Gender on Students' Conception of Heat Energy in Senior Secondary School Physics

\begin{tabular}{|c|c|c|c|c|c|c|c|c|c|c|c|c|}
\hline & & Male $(\mathbf{n}=2$ & 17) & & & emale $(n=$ & 40) & & & & & \\
\hline $\begin{array}{c}\text { Item } \\
\text { No. } \\
\end{array}$ & $\begin{array}{c}\mathrm{SC} \\
\mathbf{f}(\%) \\
\end{array}$ & $\begin{array}{c}\text { PU } \\
\mathbf{f}(\%)\end{array}$ & $\begin{array}{c}\mathrm{AC} \\
\mathbf{f}(\%) \\
\end{array}$ & $\begin{array}{c}\mathrm{NC} \\
\mathrm{f}(\%) \\
\end{array}$ & $\begin{array}{l}\text { SC } \\
\mathrm{f}(\%)\end{array}$ & $\begin{array}{c}\text { PU } \\
\mathbf{f}(\%)\end{array}$ & $\begin{array}{c}\mathbf{A C} \\
\mathbf{f}(\%) \\
\end{array}$ & $\begin{array}{c}\mathrm{NC} \\
\mathrm{f}(\%) \\
\end{array}$ & $\chi^{2}$ & Df & $\begin{array}{c}\text { p- } \\
\text { value }\end{array}$ & Decision \\
\hline 1 & $93(26.1)$ & $39(10.9)$ & $44(12.4)$ & $41(11.5)$ & $70(19.6)$ & $24(6.7)$ & $23(6.4)$ & $23(6.4)$ & $1.944^{\mathrm{a}}$ & 3 & 0.584 & NS \\
\hline 2 & $4(1.1)$ & $15(4.2)$ & $36(10.1)$ & $162(45.4)$ & $3(0.8)$ & $10(2.8)$ & $27(7.6)$ & $100(28.0)$ & $0.517^{a}$ & 3 & 0.915 & NS \\
\hline 3 & $4(1.1)$ & $10(2.8)$ & $13(3.6)$ & $190(53.2)$ & $6(1.7)$ & $2(0.5)$ & $9(2.5)$ & $123(34.5)$ & $4.399^{a}$ & 3 & 0.221 & NS \\
\hline 4 & $44(12.3)$ & $11(3.1)$ & $26(7.3)$ & $136(38.1)$ & $24(6.7)$ & $8(2.2)$ & $29(8.1)$ & $79(22.1)$ & $5.269^{a}$ & 3 & 0.153 & NS \\
\hline 5 & $1(0.3)$ & $11(3.1)$ & $31(8.6)$ & $174(48.7)$ & $1(0.3)$ & $10(2.8)$ & $26(7.3)$ & $103(28.9)$ & $2.178^{a}$ & 3 & 0.536 & NS \\
\hline 6 & $1(0.3)$ & $5(1.4)$ & $46(12.9)$ & $165(46.2)$ & $3(0.8)$ & $7(2.0)$ & $43(12.0)$ & $87(24.3)$ & $9.407^{a}$ & 3 & 0.024 & $\mathrm{~S}$ \\
\hline 7 & $3(0.8)$ & $13(3.6)$ & $39(10.9)$ & $162(45.4)$ & $0(0)$ & $2(0.5)$ & $17(4.7)$ & $121(33.9)$ & $9.483^{a}$ & 3 & 0.024 & $\mathrm{~S}$ \\
\hline 8 & $4(1.1)$ & $26(7.3)$ & $41(11.5)$ & $146(40.9)$ & $2(0.5)$ & $20(5.6)$ & $28(7.8)$ & $90(25.2)$ & $0.607^{\mathrm{a}}$ & 3 & 0.895 & NS \\
\hline 9 & $8(2.2)$ & $13(3.6)$ & $17(4.8)$ & $179(50.1)$ & $6(1.7)$ & $1(0.3)$ & $9(2.5)$ & $124(34.7)$ & $6.721^{a}$ & 3 & 0.081 & NS \\
\hline 10 & $1(0.3)$ & $6(1.7)$ & $25(7.0)$ & $185(51.8)$ & $0(0)$ & $3(0.8)$ & $17(4.8)$ & $120(33.6)$ & $0.806^{\mathrm{a}}$ & 3 & 0.848 & NS \\
\hline 11 & $1(0.3)$ & $11(3.1)$ & $30(8.4)$ & $175(49.0)$ & $0(0)$ & $10(2.8)$ & $19(5.3)$ & 111(31.1) & $1.291^{\mathrm{a}}$ & 3 & 0.731 & NS \\
\hline 12 & $1(0.3)$ & $6(7.3)$ & $27(7.6)$ & $184(51.5)$ & $2(0.5)$ & $6(1.7)$ & $21(5.9)$ & 111(31.1) & $2.435^{\mathrm{a}}$ & 3 & 0.487 & NS \\
\hline 13 & $4(1.1)$ & $26(7.3)$ & $27(7.6)$ & $160(44.8)$ & $1(0.3)$ & $13(3.6)$ & $29(8.1)$ & $97(27.2)$ & $5.286^{\mathrm{a}}$ & 3 & 0.152 & NS \\
\hline 14 & $0(0)$ & $5(1.4)$ & $29(8.1)$ & $183(51.2)$ & $0(0)$ & $1(0.3)$ & $14(3.9)$ & $125(35.0)$ & $2.321^{\mathrm{a}}$ & 3 & 0.313 & NS \\
\hline 15 & $20(5.6)$ & $21(5.9)$ & $16(4.5)$ & $160(44.8)$ & $13(3.6)$ & $17(4.8)$ & $8(2.2)$ & $102(28.6)$ & $0.844^{\mathrm{a}}$ & 3 & 0.839 & NS \\
\hline 16 & $1(0.3)$ & $14(3.9)$ & $13(3.6)$ & $189(52.9)$ & $0(0)$ & $14(3.9)$ & $8(2.2)$ & $118(33.2)$ & $2.101^{\mathrm{a}}$ & 3 & 0.552 & NS \\
\hline
\end{tabular}

NB: $n=$ Number of Respondent; $\mathrm{NC}=$ No Conception; $\mathrm{AC}=$ Alternative Conception; $\mathrm{PU}=$ Partial Understanding; $\mathrm{SC}=$ Sound/Scientific Conception; $\mathrm{f}=$ Frequency; $\%=$ Percentage; $\chi^{2}=$ Chi-Square; $\mathrm{p}$-value= Probability value; $\mathrm{df}=\mathrm{Degree}$ of freedom

The result presented in Table 2 revealed that items 1, 2, 3, 4, 5, 8, 9, 10, 11, 12, 13, 14, 15 \&16 were not significant since the probability values ranges from $(p=0.152$ to 0.895$)$ which is greater than the level of significance $(\mathrm{p}=0.05)$. Therefore, the decision is not significant (NS). Also, items 
6 and 7 whose probability values gave $(\mathrm{p}=0.024)$ which is less than the level of significance $(\mathrm{p}=0.05)$ were significant $(\mathrm{S})$. However, the above result calls for overall trace analysis so as to draw a unified conclusion on influence of gender on students' conceptions of heat energy.

Table 3: Overall Trace Analysis of Influence of Gender on Students' Conception of Heat Energy in Senior Secondary School Physics

\begin{tabular}{|c|c|c|c|c|c|c|c|c|c|c|}
\hline & \multicolumn{4}{|c|}{ Response } & \multirow[t]{2}{*}{ Total } & \multirow[t]{2}{*}{$\chi^{2}$} & \multirow[t]{2}{*}{ df } & \multirow[t]{2}{*}{ p-value } & \multirow[t]{2}{*}{ Decision } \\
\hline & & SC & PU & AC & NC & & & & & \\
\hline \multirow{3}{*}{ Gender } & Male & 12 & 14 & 29 & 162 & 217 & $0.205^{\mathrm{a}}$ & 3 & 0.977 & NS \\
\hline & Female & 8 & 9 & 21 & 102 & 140 & & & & \\
\hline & Total & 20 & 23 & 50 & 264 & 357 & & & & \\
\hline
\end{tabular}

$\mathrm{NC}=$ No Conception; AC $=$ Alternative Conception; PU = Partial Understanding; SC $=$ Sound/Scientific Conception; NS= Not Significant; $\chi^{2}=$ Chi-Square; $p$-value $=$ Probability value

The result presented in Table 3, revealed the result on influence of school location on students conception of heat energy. The probability value (0.977) was greater than the level of significance (0.05). This gave the decision that the hypothesis is NS (Not Significant). To this effect, the null hypothesis was upheld by the researcher. Thus, students' conception of heat energy in senior secondary school physics is not significantly influenced by gender.

Research question 2: What is the influence of location on students' conception of heat energy in senior secondary school physics? 
British Journal of Education

Vol.8, Issue 6, pp.1-17, June 2020

Published by ECRTD- UK

Print ISSN: ISSN 2054-6351: Online ISSN: ISSN 2054-636X

Table 4: Frequency and Percentage Analysis of Influence of School Location on Students' Conception of Heat Energy in Senior Secondary School Physics

\begin{tabular}{|c|c|c|c|c|c|c|c|c|}
\hline \multirow[b]{2}{*}{ Item No. } & \multirow[b]{2}{*}{$\begin{array}{l}\text { SC } \\
\mathbf{f}(\%)\end{array}$} & \multicolumn{2}{|c|}{ Urban $(n=262)$} & \multirow[b]{2}{*}{$\begin{array}{l}\text { NC } \\
f(\%)\end{array}$} & \multicolumn{2}{|c|}{ Rural (n=95) } & \multirow[b]{2}{*}{$\begin{array}{l}\mathrm{AC} \\
\mathbf{f}(\%)\end{array}$} & \multirow[b]{2}{*}{$\begin{array}{l}\text { NC } \\
\mathbf{f}(\%) \\
\end{array}$} \\
\hline & & $\begin{array}{l}\text { PU } \\
\mathbf{f}(\%)\end{array}$ & $\begin{array}{l}\mathrm{AC} \\
\mathrm{f}(\%) \\
\end{array}$ & & $\begin{array}{l}\text { SC } \\
\mathbf{f}(\%) \\
\end{array}$ & $\begin{array}{l}\text { PU } \\
f(\%)\end{array}$ & & \\
\hline 1 & 111(31.1) & $48(13.4)$ & $56(15.7)$ & $47(13.1)$ & $52(14.6)$ & $15(4.2)$ & $11(3.1)$ & $17(4.8)$ \\
\hline 2 & $5(1.4)$ & $11(3.1)$ & $34(9.5)$ & $212(59.4)$ & $2(0.6)$ & $14(3.9)$ & $29(8.1)$ & $50(14.0)$ \\
\hline 3 & $10(2.8)$ & $10(2.8)$ & $14(3.9)$ & $228(63.9)$ & $0(0)$ & $2(0.6)$ & $8(2.2)$ & $85(23.8)$ \\
\hline 4 & $59(16.5)$ & $10(2.8)$ & $24(6.7)$ & $169(47.3)$ & $9(2.5)$ & $9(2.5)$ & $31(8.7)$ & $46(12.9)$ \\
\hline 5 & $1(0.3)$ & $6(1.6)$ & $22(6.2)$ & $233(65.3)$ & $1(0.3)$ & $15(4.2)$ & $35(9.8)$ & $44(12.3)$ \\
\hline 6 & $4(1.1)$ & $5(1.4)$ & $53(14.9)$ & $200(56.0)$ & $0(0)$ & $7(2.0)$ & $36(10.1)$ & $52(14.6)$ \\
\hline 7 & $2(0.6)$ & $12(3.3)$ & $37(10.4)$ & $211(59.1)$ & $1(0.3)$ & $3(0.8)$ & $19(5.3)$ & $72(20.2)$ \\
\hline 8 & $5(1.4)$ & $30(8.4)$ & $51(14.3)$ & $176(49.3)$ & $1(0.3)$ & $16(4.5)$ & $18(5.0)$ & $60(16.8)$ \\
\hline 9 & $12(3.3)$ & $13(3.6)$ & $18(5.0)$ & $219(61.3)$ & $2(0.6)$ & $1(0.3)$ & $8(2.2)$ & $84(23.5)$ \\
\hline 10 & $1(0.3)$ & $4(1.1)$ & $24(6.7)$ & $233(65.3)$ & $0(0)$ & $10(2.8)$ & $22(6.2)$ & $63(17.6)$ \\
\hline 11 & $1(0.3)$ & $11(3.1)$ & $27(75.6)$ & $223(65.3)$ & $0(0)$ & $10(2.8)$ & $22(6.2)$ & $63(17.6)$ \\
\hline 12 & $1(0.3)$ & $9(2.5)$ & $30(8.4)$ & $222(62.1)$ & $2(0.6)$ & $3(0.8)$ & $17(4.8)$ & $73(20.5)$ \\
\hline 13 & $5(1.4)$ & $28(7.8)$ & $36(10.1)$ & $193(54.1)$ & $0(0)$ & $11(3.1)$ & $20(5.6)$ & 64(17.9) \\
\hline 14 & $0(0)$ & $3(0.8)$ & $33(9.2)$ & $226(63.3)$ & $0(0)$ & $3(0.8)$ & $10(2.8)$ & $82(23)$ \\
\hline 15 & $19(5.3)$ & $29(8.2)$ & $19(5.3)$ & $195(54.6)$ & 14(3.9) & $9(2.5)$ & $5(1.4)$ & $67(18.8)$ \\
\hline 16 & $1(0.3)$ & $18(5.0)$ & $17(4.8)$ & $226(63.3)$ & $0(0)$ & $10(2.8)$ & $4(1.1)$ & $81(22.7)$ \\
\hline $\begin{array}{l}\text { Overall } \\
\text { No. of } \\
\text { Students }\end{array}$ & $15(4.2)$ & $15(4.2)$ & 31(8.6) & $201(56.3)$ & $5(1.4)$ & $9(2.5)$ & $18(5)$ & $63(17.7)$ \\
\hline
\end{tabular}

$\mathrm{NB}$ : The overall number of students in each level of conception is equal to frequency divided by number of items (ie. 16); $\mathrm{NC}=$ No Conception; $\mathrm{AC}=$ Alternative Conception; $\mathrm{PU}=$ Partial Understanding; $\mathrm{SC}=\mathrm{Sound} / \mathrm{Scientific}$ Conception; $\mathrm{f}=$ Frequency; \% = percentage; $\mathrm{n}=$ Number of Respondent

Analysis in Table 4 shows that item1 have 111, 48, 56 and 47 urban students who have SC, PU, $\mathrm{AC}$ and $\mathrm{NC}$ of item1 respectively. However, rural student(s) who have SC, PU, AC and NC of 
British Journal of Education

Vol.8, Issue 6, pp.1-17, June 2020

Published by ECRTD- UK

Print ISSN: ISSN 2054-6351: Online ISSN: ISSN 2054-636X

item1 are 52, 15, 11 and 17 respectively. Also in item2, 5, 11, 34 and 212 urban students who have SC, PU, AC and NC of item2, respectively while rural students who have SC, PU, AC and NC of item 2 are 50, 29, 14 and 2 respectively. In item3, 10, 10,14 and 228 urban students who have SC, PU, AC and NC of item 3 respectively whereas rural student(s) who have SC, PU, AC and NC of item3 are 0, 2, 8 and 85 respectively. In item4, 59, 10, 24 and 169 urban students who have SC, PU, AC and NC of item4 respectively while rural student(s) who have SC, PU, AC and NC of item 4 are 9, 9, 31 and 46 respectively.

In item5, 1 student has SC and 6 students have PU while 22 students have AC and 233 students have NC all for urban student respondents of item5. However, one rural student has SC and 15 students have PU while 35 students have AC and 44 have NC of item5. In item6, 4 students have SC and 5 students have PU while 53 students have AC and 200 students have NC all for urban student respondents of item6. However, rural students who have SC is none, 7 students have PU while 36 students have AC and 52 have NC of item6. In item7, 2 students have SC and 12 students have PU while 37 students have AC and 211 students have NC all for urban student respondents of item7. Also, rural students who have SC are 1; 3 students have PU while 19 students have AC and 72 have $\mathrm{NC}$ of item7. In item8, 5 students have SC and 30 students have PU while 51 students have AC and 176 students have NC all for urban student respondents of item8. Also, rural student who have SC is $1 ; 16$ students have PU; 18 students have AC while 60 students have NC of item8.

In item9, 12, 13, 18 and 219 urban students who have SC, PU, AC and NC of item9 respectively while rural student(s) who have SC, PU, AC and $\mathrm{NC}$ of item9 are 2, 1, 8 and 84 respectively. In item10, 1, 4, 24 and 233 urban student(s) who have SC, PU, AC and NC of item10 respectively while rural student(s) who have SC, PU, AC and NC of item10 are 0,10, 22 and 63 respectively. In item11, 1, 11, 27 and 233 urban students who have SC, PU, AC and NC of item11 respectively while rural student(s) who have SC, PU, AC and NC of item11 are 0, 10, 22and 63 respectively. In item12, 1, 9, 30 and 222 urban students who have SC, PU, AC and NC of item12 respectively while rural student(s) who have SC, PU, AC and $\mathrm{NC}$ of item12 are 2, 3, 17 and 73 respectively. In item13, 5, 28, 36 and 193 urban students who have SC, PU, AC and NC of item13 respectively while rural student(s) who have SC, PU, AC and NC of item13 are 0, 11, 20 and 64 respectively.

In item14, 226, 33, 3 and 0 urban student(s) who have NC, AC, PU and SC of item14 respectively whereas rural student(s) who have NC, AC, PU and SC of item14 are 82, 10, 3, and 0 respectively. In item15, 195, 19, 29 and 19 urban students who have NC, AC, PU and SC of item15 respectively while rural student(s) who have $\mathrm{NC}, \mathrm{AC}, \mathrm{PU}$ and SC of item 15 are 67, 5, 9, and 14 respectively. In item16, 226, 17, 18 and 1 urban students who have $\mathrm{NC}, \mathrm{AC}, \mathrm{PU}$ and $\mathrm{SC}$ of item 16 respectively while rural student(s) who have $\mathrm{NC}, \mathrm{AC}, \mathrm{PU}$ and $\mathrm{SC}$ of item16 are 81, 4, 10, and 0 respectively.

Analysis in table 4 also shows the overall $\mathrm{f}(\%)$ of urban students that have SC-15(4.2\%); PU15(4.2\%); AC-31(8.7\%) and NC-201(56.3\%). On the aspect of rural students; $5(1.4 \%)$ have SC; $9(2.5 \%)$ have PU; 18(5\%) have AC and 63(17.7\%) have NC. This indicates that both urban and rural students have lowest frequency on $\mathrm{SC}$ which is the required conception when compared with other level of students' conception (ie. PU, AC, NC). However, the chart below revealed how students' response which has been categorized into levels was distributed among school location. The tallest bar in both locations (urban and rural) which is NC shows that students do not have the 
British Journal of Education

Vol.8, Issue 6, pp.1-17, June 2020

Published by ECRTD- UK

Print ISSN: ISSN 2054-6351: Online ISSN: ISSN 2054-636X

required conception of HECT since SC has the smallest bar. Nevertheless, the influence of school location on students' conception of heat energy was further investigated by testing the hypothesis below.

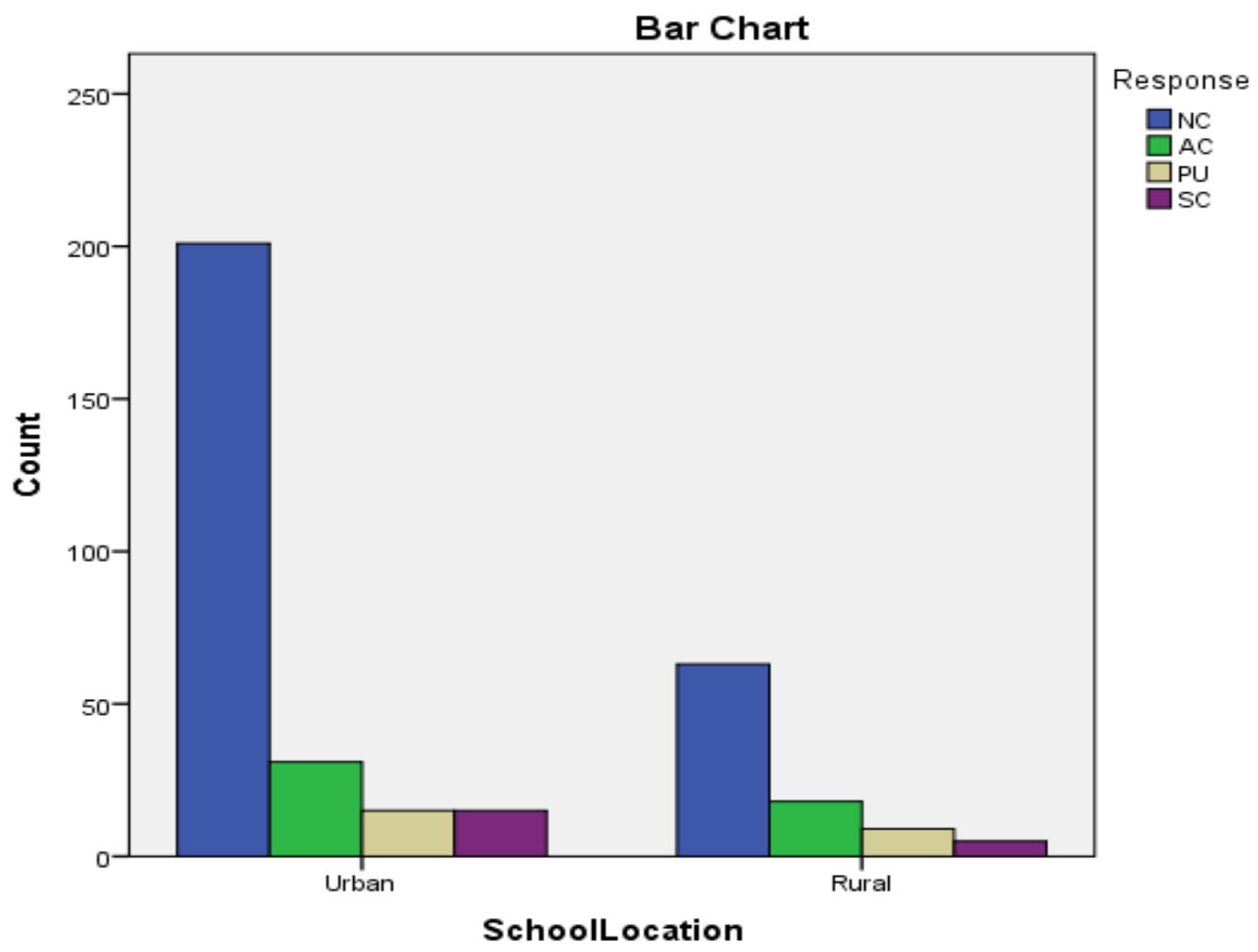

Fig 2: Histogram Showing the Distribution of School Location on Overall Conception of Heat Energy Conception Test (HECT)

Hypotheses 2: Students' conception of heat energy in senior secondary school physics is not significantly influenced by school location. 
British Journal of Education

Vol.8, Issue 6, pp.1-17, June 2020

Published by ECRTD- UK

Print ISSN: ISSN 2054-6351: Online ISSN: ISSN 2054-636X

Table 5: Chi-square Analysis of School Location on Students' Conception of Heat Energy in Senior Secondary School Physics

\begin{tabular}{|c|c|c|c|c|c|c|c|c|c|c|c|c|}
\hline \multirow[b]{2}{*}{$\begin{array}{l}\text { Item } \\
\text { No. } \\
\end{array}$} & \multirow[b]{2}{*}{$\begin{array}{l}\mathrm{SC} \\
\mathrm{f}(\%) \\
\end{array}$} & \multicolumn{2}{|c|}{ Urban $(n=262)$} & \multirow[b]{2}{*}{$\begin{array}{l}\mathrm{NC} \\
\mathrm{f}(\%) \\
\end{array}$} & \multicolumn{2}{|c|}{ Rural (n=95) } & \multirow[b]{2}{*}{$\begin{array}{l}\mathrm{AC} \\
\mathbf{f}(\%) \\
\end{array}$} & \multirow[b]{2}{*}{$\begin{array}{l}\mathbf{N C} \\
\mathbf{f}(\%) \\
\end{array}$} & \multirow[b]{2}{*}{$\chi^{2}$} & \multirow[b]{2}{*}{ Df } & \multirow[b]{2}{*}{ p-value } & \multirow[b]{2}{*}{ Decision } \\
\hline & & $\begin{array}{l}\text { PU } \\
\mathbf{f}(\%)\end{array}$ & $\begin{array}{l}\mathbf{A C} \\
\mathbf{f}(\%)\end{array}$ & & $\begin{array}{l}\text { SC } \\
\mathbf{f}(\%) \\
\end{array}$ & $\begin{array}{l}\text { PU } \\
\mathbf{f}(\%)\end{array}$ & & & & & & \\
\hline 1 & 111(31.1) & $48(13.4)$ & $56(15.7)$ & $47(13.1)$ & $52(14.6)$ & $15(4.2)$ & $11(3.1)$ & $17(4.8)$ & $6.154^{\mathrm{a}}$ & 3 & 0.104 & NS \\
\hline 2 & $5(1.4)$ & $11(3.1)$ & $34(9.5)$ & 212(59.4) & $2(0.6)$ & $14(3.9)$ & $29(8.1)$ & $50(14.0)$ & $30.838^{a}$ & 3 & 0.000 & $S$ \\
\hline 3 & $10(2.8)$ & $10(2.8)$ & $14(3.9)$ & $228(63.9)$ & $0(0)$ & $2(0.6)$ & $8(2.2)$ & $85(23.8)$ & $5.353^{\mathrm{a}}$ & 3 & 0.148 & NS \\
\hline 4 & $59(16.5)$ & $10(2.8)$ & $24(6.7)$ & $169(47.3)$ & $9(2.5)$ & $9(2.5)$ & $31(8.7)$ & $46(12.9)$ & $38.346^{\mathrm{a}}$ & 3 & 0.000 & S \\
\hline 5 & $1(0.3)$ & $6(1.6)$ & $22(6.2)$ & $233(65.3)$ & $1(0.3)$ & $15(4.2)$ & $35(9.8)$ & $44(12.3)$ & $73.810^{\mathrm{a}}$ & 3 & 0.000 & $S$ \\
\hline 6 & $4(1.1)$ & $5(1.4)$ & $53(14.9)$ & $200(56.0)$ & $0(0)$ & $7(2.0)$ & $36(10.1)$ & $52(14.6)$ & $20.969^{a}$ & 3 & 0.000 & $S$ \\
\hline 7 & $2(0.6)$ & $12(3.3)$ & $37(10.4)$ & 211(59.1) & $1(0.3)$ & $3(0.8)$ & $19(5.3)$ & $72(20.2)$ & $2.139^{\mathrm{a}}$ & 3 & 0.544 & NS \\
\hline 8 & $5(1.4)$ & $30(8.4)$ & $51(14.3)$ & $176(49.3)$ & $1(0.3)$ & $16(4.5)$ & $18(5.0)$ & $60(16.8)$ & $2.057^{\mathrm{a}}$ & 3 & 0.561 & NS \\
\hline 9 & $12(3.3)$ & $13(3.6)$ & $18(5.0)$ & $219(61.3)$ & $2(0.6)$ & $1(0.3)$ & $8(2.2)$ & $84(23.5)$ & $4.228^{\mathrm{a}}$ & 3 & 0.238 & NS \\
\hline 10 & $1(0.3)$ & $4(1.1)$ & $24(6.7)$ & $233(65.3)$ & $0(0)$ & $10(2.8)$ & $22(6.2)$ & $63(17.6)$ & $11.309^{\mathrm{a}}$ & 3 & 0.010 & $S$ \\
\hline 11 & $1(0.3)$ & $11(3.1)$ & $27(75.6)$ & $223(65.3)$ & $0(0)$ & $10(2.8)$ & $22(6.2)$ & $63(17.6)$ & $16.575^{\mathrm{a}}$ & 3 & 0.001 & $\mathrm{~S}$ \\
\hline 12 & $1(0.3)$ & $9(2.5)$ & $30(8.4)$ & $222(62.1)$ & $2(0.6)$ & $3(0.8)$ & $17(4.8)$ & $73(20.5)$ & $5.205^{\mathrm{a}}$ & 3 & 0.157 & NS \\
\hline 13 & $5(1.4)$ & $28(7.8)$ & $36(10.1)$ & $193(54.1)$ & $0(0)$ & $11(3.1)$ & $20(5.6)$ & 64(17.9) & $4.624^{\mathrm{a}}$ & 3 & 0.201 & NS \\
\hline 14 & $0(0)$ & $3(0.8)$ & $33(9.2)$ & $226(63.3)$ & $0(0)$ & $3(0.8)$ & $10(2.8)$ & $82(23)$ & $1.929^{\mathrm{a}}$ & 3 & 0.381 & NS \\
\hline 15 & $19(5.3)$ & $29(8.2)$ & $19(5.3)$ & $195(54.6)$ & $14(3.9)$ & $9(2.5)$ & $5(1.4)$ & $67(18.8)$ & $4.947^{\mathrm{a}}$ & 3 & 0.176 & NS \\
\hline 16 & $1(0.3)$ & $18(5.0)$ & $17(4.8)$ & $226(63.3)$ & $0(0)$ & $10(2.8)$ & $4(1.1)$ & $81(22.7)$ & $2.174^{\mathrm{a}}$ & 3 & 0.537 & NS \\
\hline & $\begin{array}{l}\mathrm{NB}: \mathrm{NC}=\mathrm{N} \\
\text { Conception; } \\
\mathrm{df}=\text { Degree o }\end{array}$ & $\begin{array}{l}\text { Concepti } \\
\text { Frequency } \\
\text { Freedom }\end{array}$ & $\begin{array}{l}\mathrm{n} ; \mathrm{AC}= \\
\%=\text { perce }\end{array}$ & $\begin{array}{l}\text { Alternative } \\
\text { entage; } n=1\end{array}$ & רeept10 & $\mathrm{PU}=\mathrm{P}$ & tial Und & standing; & $\begin{array}{l}\mathrm{SC}=\text { Soun } \\
\mathrm{ue}=\text { Proba }\end{array}$ & $/ \mathrm{Sci}$ & $\begin{array}{l}\text { tific } \\
\text { lue; }\end{array}$ & \\
\hline & $\begin{array}{l}\text { Analysis in } \\
\text { he probab } \\
\text { significanc } \\
11 \text { whose } \\
\text { significanc } \\
\text { so as to dra }\end{array}$ & $\begin{array}{l}\text { able } 5 \text { r } \\
\text { ty value } \\
(\mathrm{p}=0.05) \\
\text { obability } \\
\mathrm{p}=0.05)\end{array}$ & $\begin{array}{l}\text { evealed th } \\
\text { Therefor } \\
\text { values }\end{array}$ & $\begin{array}{l}\text { lat items } 1 \text {, } \\
\text { from }(\mathrm{p}= \\
\text { re, the deci } \\
\text { ranges fro } \\
\text { hificant }(\mathrm{S}) \\
\text { luence of } \mathrm{s}\end{array}$ & $\begin{array}{l}, 7,8,9, \\
0.104 \text { to } \\
\text { on is not } \\
(p=0.0\end{array}$ & $\begin{array}{l}12,13, \\
0.561) \\
\text { signific } \\
0 \text { to } 0.0 \\
\text { above } \mathrm{f} \\
\text { ation stu }\end{array}$ & $\begin{array}{l}14,15 \& \\
\text { which is } \\
\text { ant (NS). } \\
10 \text { ) whic }\end{array}$ & $\begin{array}{l}6 \text { were n } \\
\text { greater } \\
\text { Also, ite } \\
\mathrm{h} \text { is less } \\
\text { lls for ov } \\
\text { ceptions }\end{array}$ & $\begin{array}{l}\text { ot signifi } \\
\text { than the } \\
\text { ms } 2,4 \text {, } \\
\text { than the }\end{array}$ & $\begin{array}{l}\text { ant } \\
\text { lev } \\
6, \\
\text { lev }\end{array}$ & $\begin{array}{l}\text { nce } \\
\text { of } \\
\& \\
\text { of } \\
\text { ysis }\end{array}$ & \\
\hline
\end{tabular}


British Journal of Education

Vol.8, Issue 6, pp.1-17, June 2020

Published by ECRTD- UK

Print ISSN: ISSN 2054-6351: Online ISSN: ISSN 2054-636X

Table 6: Overall Trace Analysis of Influence of School Location on Students' Conception of Heat Energy in Senior Secondary School Physics

\begin{tabular}{|c|c|c|c|c|c|c|c|c|c|c|}
\hline & \multicolumn{4}{|c|}{ Response } & \multirow[t]{2}{*}{ Total } & \multirow{2}{*}{\multicolumn{2}{|c|}{$\chi^{2} \quad$ df }} & \multirow[t]{2}{*}{ p-value } & \multirow[t]{2}{*}{ Decision } \\
\hline & & SC & $\mathbf{P U}$ & $\mathbf{A C}$ & NC & & & & & \\
\hline \multirow{3}{*}{ School Location } & Urban & 15 & 15 & 31 & 201 & 262 & $5.076^{\mathrm{a}}$ & 3 & 0.166 & NS \\
\hline & Rural & 5 & 9 & 18 & 63 & 95 & & & & \\
\hline & Total & 20 & 24 & 49 & 264 & 357 & & & & \\
\hline
\end{tabular}

$\mathrm{NC}=$ No Conception; AC $=$ Alternative Conception; PU = Partial Understanding; SC $=$ Sound/Scientific Conception; $\mathrm{NS}=$ Not Significant; $\chi^{2}=$ Chi-Square $; \mathrm{p}$-value $=$ Probability value $; \mathrm{df}=$ Degree of Freedom

The result presented in Table 6, summarizes the of influence of school location on students conception of heat energy; it can be seen that probability value (0.166) was greater than the level of significance (0.05). This gave the decision that the hypothesis is NS (Not Significant). To this effect, the null hypothesis was upheld by the researcher. Thus, students' conception of heat energy in senior secondary school physics is not significantly influenced by school location.

\section{DISCUSSION}

Finding revealed that both male and female students possess NC which is naive or no conception of heat energy concept. Thus, male and female students' conception of heat energy is not scientific or sound when compared with other levels of conception (i.e. PU, AC, NC). Also, finding showed that students' conception of heat energy in senior secondary school physics is not significantly influenced by gender. This could as a result of close range of male and female students in each of their conception frequency level. Nwankwo and Madu (2014); Zudonu (2013) on a separate study identified gender and teaching method to have no significant effect on students' conceptual change in physics and practical chemistry contents (acids and bases). The present study is in consonance with this study. However, this finding is in alignment with the findings of Orji and Zudonu (2017) who revealed that gender has no statistical influence on students' conceptions of energy.

On the contrary, Demirci and Cirkinoglu (2004) study disagreed with the present study. The study showed that there is significant difference between gender and students' conception in electricity and magnetism concepts. However, the difference between the finding of this study and the present study may be attributed to different design and method of data analysis used. Demirci and Cirkinoglu (2004) used ANOVA, mean and standard deviation for data analysis and descriptive design while the present study used chi-square, frequency and percentage for data analysis, and ex-post facto research design. The disagreement in the finding of both studies could be attributed to the instrument used for data collection, geographical and content scope, and design. The study was on all undergraduate biology students in Taiwan universities; questionnaire was used for data collection; correlation research design. While the present study used SS2 physics students in Onitsha education zone of Anambra State; HECT was used for data collection; descriptive and expost facto research design was used.

From the findings, both urban and rural students have naive or no conception of heat energy. This implies that students in both locations do not have the required conception about heat energy. This 
British Journal of Education

Vol.8, Issue 6, pp.1-17, June 2020

Published by ECRTD- UK

Print ISSN: ISSN 2054-6351: Online ISSN: ISSN 2054-636X

finding also revealed that students' conception of heat energy in senior secondary school physics is not significantly influenced by school location. The finding could be attributed to physics curriculum used by both locations which do not take cognizance of how students conceives a concept. However, Ugwuanyi (2012) carried a study on assessment of senior secondary school students' conceptual understanding of force and motion. It was revealed from the study that school location has no significant influence on the students' conceptual understanding of force and motion. This is in agreement with the present study. Also, the study by Rafael (2014) showed that there is no significant difference between school location and students' conceptions in physics. This finding is in consonance with the present study.

On the contrary, Nworgu, Ugwuanyi and Nworgu (2013) in a study titled investigation on school location and gender as factors in senior secondary school students' conceptual understanding of force and motion found that gender and school location were significant $(p<0.05)$ factors in students' understanding of force and motion. This finding disagrees with the finding of the present study. The discrepancy between the findings of the both studies may be attributed to their different content area in physics and location of study.

\section{CONCLUSION AND RECOMMENDATIONS}

Based on the findings of the study and discussion that follows, the following conclusion were made, thus; gender and school location are significant factors in determining students conception of heat energy in senior secondary school physics.

1. Physics teachers should endeavour to possess the required scientific conception about heat energy. This will help bring students to sound conception level.

2. Authors' of physics textbooks, practical books and workbooks should take cognizance of students' mixed state and conception levels while writing. This will help improve students understanding of physics concepts particularly heat energy.

3. Curriculum planner should ensure that the way students' conceive a concept is considered and included in the Physics curriculum.

\section{REFERENCES}

Agomuoh, P.C. (2010). Effect of prior knowledge, exploration, discussion, dissatisfaction with prior knowledge and application (PEDDA) and the learning cycle (TLC) constructivist instructional models on students' conceptual change and retention. 'An Unplished Ph.D Thesis,' UNN.

Amaechi, C.C. (2013). Effects of the learning cycle model on students understanding of physics concepts. 'An Unpublished Thesis,' University of Nigeria, Nsukka.

Arigbadu, A.A. \& Miji, A. (2014). Is gender a factor in mathematics performance among Nigeria preservice teachers? Retrieved September $2^{\text {nd }}, \quad 2018, \quad$ from www.academia.edu//./\&6978/Is_gender_a_factor_in_mathematics_performance_among_Nigeria.

Bekele, G.D., Jeanne, K. \& Temesgen, F.M. (2013). Students' conceptual change in electricity and magnetism using simulations: A comparison of cognitive perturbation and cognitive conflict. Journal of Research in Science Teaching, 50(6), 215-234. doi://10.1002/tea.21096

Bilesanmi-Awoderu, J.B., (2006). Effect of computer assisted instruction and simulation/games on the academic achievement of secondary school students in biology. Sokoto Educational Review, 8(1), 49-60. 
British Journal of Education

Vol.8, Issue 6, pp.1-17, June 2020

Published by ECRTD- UK

Print ISSN: ISSN 2054-6351: Online ISSN: ISSN 2054-636X

Chinyere, N.M. \& Madu, B.C. (2014). Effect of analogy teaching approach on students' conceptual change in Physics. Green Journal of Educational Research, 4(4), 119-125.

Chiou, G., Liang, J. \& Tsai, C. (2012). Undergraduate students' conceptions and approaches to learning in biology: a study of their structural models and gender differences. International Journal of Science Education, 34(2), 167-195.

Demirci, N. \& Cirkinoglu, A. (2004). Determining students' conception in electricity and magnetism concepts. Journal of Turkish Science Education 1(2),51-57.

Demirci, N. \& Cirkinoglu, A. (2004). Determining students' conception in electricity and magnetism concepts. Journal of Turkish Science Education 1(2), 51-57.

Fatoba, J.O. \& Aladejana, A.L. (2014). Effect of gender on students' attitude to physics in secondary schools in Oyo state, Nigeria. European Scientific Journal, 10(7), 399-404.

Fries-Gaither, J. (2009). Common misconception about heat and insulation. National Science Education Standards. Retrieved September $27^{\text {th }}, 2018$, from www.beyondpenguis.ehe.osu.edu/issue/keepingwarm/common-misconception-about-heat-and-instulation.

Hofstein, A. \& Kesner, M. (2016). Industrial chemistry and school chemistry: making chemistry studies more relevant. International Journal of Science Education 28(9), 1017-1030.

https://www.sciencelearninghub.org.nz/students-conception-of-heat

Madu, B.C. (2004). Effect of a constructivist based instructional model on students' conceptual change and retention in physics. 'An Unpublished Thesis,' University of Nigeria, Nsukka.

Musibau, A.Y. \& Johnson, T.A. (2017). The influence of school sex, location and type on students' conception of science. International Journal of Educational Sciences, 2(2), 81-85.

Ntibi, J.E. \& Edoho, E.A. (2017). Influence of school location on students attitude towards Mathematics and Basic Science. British Journal of Education, 5(10), 76-85.

Nwankwo, C.M. \& Madu, B.C. (2014). Effect of analogy teaching approach on students' conceptual change in Physics. Green Journal of Educational Research, 4(4), 119-125.

Nworgu B. G. (2015). Educational measurement and evaluation: theory and practice. Nsukka: University Trust Publisher.

Nworgu, B.G., Ugwuanyi, C.S. \& Nworgu, L.N. (2014). School location and gender as a factor in senior secondary school students' conceptual understanding of force and motion. International Journal of Educational Research and Technology, 4(4), 71-76.

Nwosu, A.A. (2011). Gender and acquisition of science process skills among secondary school students: implications for science teaching. $42^{\text {nd }}$ Annual Conference Proceedings of STAN. Women in Science, Technology and Mathematics Education in Nigeria, 206-209.

Okorie, E.U. (2014). Effects of instructional software package on students' achievement and interest in chemical bonding. "An Unpublished Ph.D Thesis," University of Nigeria Nsukka.

Orji, E.I. \& Zudonu, O.C. (2017). Energy conceptions among science students for sustainability development. International Journal of Studies in Education, 15(2), 64-73.

Orji, E.I. (2013). Relative effect of cognitive conflict instructional strategy and conceptual change pedagogy on students' conceptual change and attention in temperature and heat. "An Unpublished Thesis," University of Nigeria, Nsukka.

Rafael, C. (2014). Senior secondary schools students' conceptions in physics. Retrieved from March $18^{\text {th }}$, 2019, from https://nairaproject.com/m/projects/3365.html

Sciencelearn. (2018). Heat energy. Retrieved September $4^{\text {th }}$, 2018, from www.sciencelearn.org.nz/resources/750-heat-energy

Shuell, T.J. (2006). Cognitive conception of learning. Review of educational research, 56(4), 411-436. doi://10.3102/00346543056004411

Tao,J., Sanjun, W., Jingying, W., \& Yongjun, M. (2018). Effect of different instructional methods on students' conceptual change regarding electrical resistance as viewed from a systhesized theoretical 
Vol.8, Issue 6, pp.1-17, June 2020

Published by ECRTD- UK

Print ISSN: ISSN 2054-6351: Online ISSN: ISSN 2054-636X

framework. Eurasia Journal of Mathematics Science and Technology Education, 14(7), 27712786.

Ugwuanyi, C.S. (2012). Assessment of senior secondary students' conceptual understanding on force and motion. 'An Unpublished M.Ed Thesis,' University of Nigeria, Nsukka.

Ugwuanyi, C.S. (2012). Assessment of senior secondary students' conceptual understanding on force and motion. (An Unpublished M.Ed Thesis),University of Nigeria, Nsukka, Enugu State.

West African Examination Council (WAEC), 2015-2017. Chief Examiners Reports. Retrieved September $3^{\text {rd }}, 2018$, from www.waeconline.org.ng/e-learning/physics/physmain.html

Zacharia, Z.C. (2017). Comparing and combining real and virtual experimentation: an effort to enhance students' conceptual understanding of electric circuits. Journal of Assisted Learning 23(2), 120132.

Zudonu, O.C. (2013). The effect of laboratory instructional methods on students' conceptual change, achievement and attitude to some chemistry concepts at senior secondary school level. 'An Unpublished Thesis,' University of Nigeria, Nsukka.

Zudonu, O.C. (2013). The effect of laboratory instructional methods on students' conceptual change, achievement and attitude to some chemistry concepts at senior secondary school level. (An Unpublished M.Ed Thesis),University of Nigeria Nsukka, Enugu State. 